\title{
What Muscardinus avellanarius like but consultants don't: performance of nest boxes vs. nest tubes for translocations (Rodentia: Gliridae)
}

Co oblibují plšíci lískoví (Muscardinus avellanarius) avšak konsultanti nikoli: úspěšnost užití hnízdních budek a hnízdních rourek pro přemist'ovací projekty (Rodentia: Gliridae)

\author{
Johannes LANG ${ }^{1,2}$, Ines LEONHARDT ${ }^{1}$, Sarah BEER ${ }^{1}$, Nicolle BRÄSEL ${ }^{1}$, Johann D. LANZ ${ }^{1,2}$ \\ \& Daniel SCHMITTFULL ${ }^{3}$ \\ ${ }^{1}$ Institute for Animal Ecology and Nature Education, Hauptstraße 30, D-35321 Laubach, Germany \\ ${ }^{2}$ Clinic for Birds, Reptiles, Amphibians and Fish, Working Group for Wildlife Biology, \\ Justus-Liebig-University Giessen, Frankfurter Straße 91-93, D-35392 Giessen, Germany; \\ johannes.lang@vetmed.uni-giessen.de \\ ${ }^{3}$ DEGES Deutsche Einheit Fernstraßenplanungs und -bau GmbH, Zimmerstraße 54, \\ D-10117 Berlin, Germany
}

received on 4 June 2018

\begin{abstract}
Nest boxes and nest tubes are widely used for surveys, for both research and development purposes, to detect and survey hazel dormice (Muscardinus avellanarius). In order to compare the performance of the two devices for translocations a study was conducted where hazel dormice had the choice between nest boxes and nest tubes. Hazel dormice preferred nest tubes over nest boxes but escaped more often from nest tubes than from nest boxes during checking. We conclude that nest boxes are the better choice for translocations as they offer the better escape ratio over nest tubes.
\end{abstract}

Key words. Hazel dormouse, mitigation, handling.

\section{INTRODUCTION}

Research and monitoring of elusive animals is always difficult. This is especially true for small, nocturnal mammals that are only active during half of the year due to hibernation, such as dormice. Choosing the right methods is crucial for successful studies of such animals. In the past the invention of novel methods has always advanced our understanding about dormice and their biology. Prominent examples are the search for hazel nuts opened by hazel dormice (Muscardinus avellanarius) that became one of the most commonly used methods to map the distribution of this species (BRIGHT et al. 1996, 2006, BüCHNER et al. 2009) or the setup of nest boxes (and later nest tubes) that is now the standard method to detect, investigate, monitor and/or capture dormice (Morris et al. 1990, JušKaitis 1997, Chanin \& Gubert 2011, Williams et al. 2013).

This contribution has been presented at the 10th International Dormouse Conference held at the University of Liège, Belgium, on 11-15 September 2017 
Depending on the research question of a project, direct and indirect methods can be used to achieve the results required. Indirect methods such as the search for animal tracks and signs (e.g. search for opened hazel nuts or summer nests), are often less labour-intensive and can be applied to greater areas than direct methods (e.g. counting animals in nest boxes or nest tubes). For some research questions it is nevertheless necessary to use direct methods. A special circumstance using direct methods is development projects in dormouse habitats, where consultants need to assess potential impacts of the proposed development on hazel dormice and recommend appropriate mitigation measures in order to avoid the deliberate killing or injury of animals as well as habitat degradation. In general, this can be done in different ways (BRIGHT et al. 2006). When animals cannot relocate on their own, one option is to translocate them by catching and releasing them in other suitable habitats (translocation). In the course of a translocation, hazel dormice are usually captured in nest boxes, in which they are transported to a release site (recommendations in BRIGHT et al. 2006). Instead of using nest boxes, some authorities recommend nest tubes for the purpose of capturing animals to be translocated because nest tubes are easier to install, cheaper and, at least in some cases they are reported to be preferred by dormice, compared to nest boxes (M. Simon pers. comm., but see CHANIN \& GuBERT 2011).

During an ongoing development project nest boxes and nest tubes were used in equal numbers to capture hazel dormice for translocation. In order to compare the two methods, boxes and tubes were set up in a way that a comparison was possible without compromising the aim of the mitigation measure.

\section{MATERIAL AND METHODS}

The study site is part of an ongoing development project where the new highway A44 is currently under construction. This highway is a German Unification Transport Project and part of the trans-European transport network. It is for the purpose of closing gaps in the transport system between former East- and West-Germany. The section where the study took place is located in the north-east of the German federal state of Hesse (coordinates: $51^{\circ} 04^{\prime} \mathrm{N}, 09^{\circ} 56^{\prime} \mathrm{E}$ ) at an altitude between $200 \mathrm{~m}$ and $350 \mathrm{~m}$, well inside the known range of the hazel dormouse in this part of Germany (BüCHNER et al. 2014). Since the highway leads through a corridor of high ecological value, extensive measures were taken to protect the existing fauna and flora. Part of the measures are the establishment of new information and the conservation, as well as optimization of existing habitats of the hazel dormouse. To compensate for the loss of about 38 ha of potential habitat, compensation areas for continuous ecological functionality-measures were provided.

The area affected by the development included 38 ha of potential hazel dormouse habitat (forest, forest edges and hedgerows) divided into 47 sub-sites along and adjacent to the future highway. All these sub-sites where well connected to other potential dormouse habitats. These habitats included semi-natural broad-leaved forests with European beech (Fagus sylvatica), common oak (Quercus robur) and European hornbeam (Carpinus betulus) as the dominating tree species, as well as conifer plantations made from Norway spruce (Picea abies) and Douglas fir (Pseudotsuga menziesii) and species rich hedgerows.

On the remaining 47 sub-sites of different size a total of 682 nest boxes and 666 nest tubes were installed. The overall density of boxes and tubes was 35.7 units/ha.

The nest boxes (size $22 \times 9.5 \times 9.5 \mathrm{~cm}$ ) were made from rough-cut wood and had $25 \mathrm{~mm}$ diameter entrance holes facing the tree. Nest tubes (size $30 \times 6.7 \times 6.7 \mathrm{~cm}$ ) were the standard model made from plastic tree guard material, with a wooden tray inside and a wooden block, sealing the tube at one end.

At 4 out of the 47 sub-sites, nest boxes and tubes were put next to each other to test whether dormice preferred one of the two devices. These sites are referred to as "comparison sites" in the text. Usually a tube was fixed on the same tree or bush as a box. If this was not possible, they were hung up as close as possible (distance $<2 \mathrm{~m}$ ). To use the same tree or bush species for both of the devices was attempted in order to avoid influence of individual habitat preferences by dormice. Altogether, 156 nest boxes and 
156 nest tubes were hung up at the 4 comparison sites (11.1 ha in total). The density of boxes and tubes per hectare was $30.7,32.6,40.3$ and 43.5 , respectively.

Surveys took place on 12 occasions between 10 May and 8 November 2017. During monitoring the nest boxes and nest tubes were carefully approached and entrance holes blocked to prevent animals from escaping. Every nest box and nest tube were then thoroughly checked for dormice or other inhabitants and nests. When dormice were present, the captured animals were translocated inside the box or tube respectively.

For calculations, only adult animals and independent juveniles where used because juveniles that are still dependent on their mother do not choose nesting sites by themselves.

\section{RESULTS}

Altogether 140 hazel dormice were found and 108 of them translocated; 28 animals escaped and two females with litters could not be translocated in order to avoid disturbance of their new-borns.

Apart from hazel dormice, other species including edible dormouse (Glis glis) (only one single animal), wood mice (Apodemus), bats, tits, wasps (including hornets) and ants were detected. Apodemus mice were the most abundant occupants of the nest boxes (288 animals) and nest tubes (68 animals).
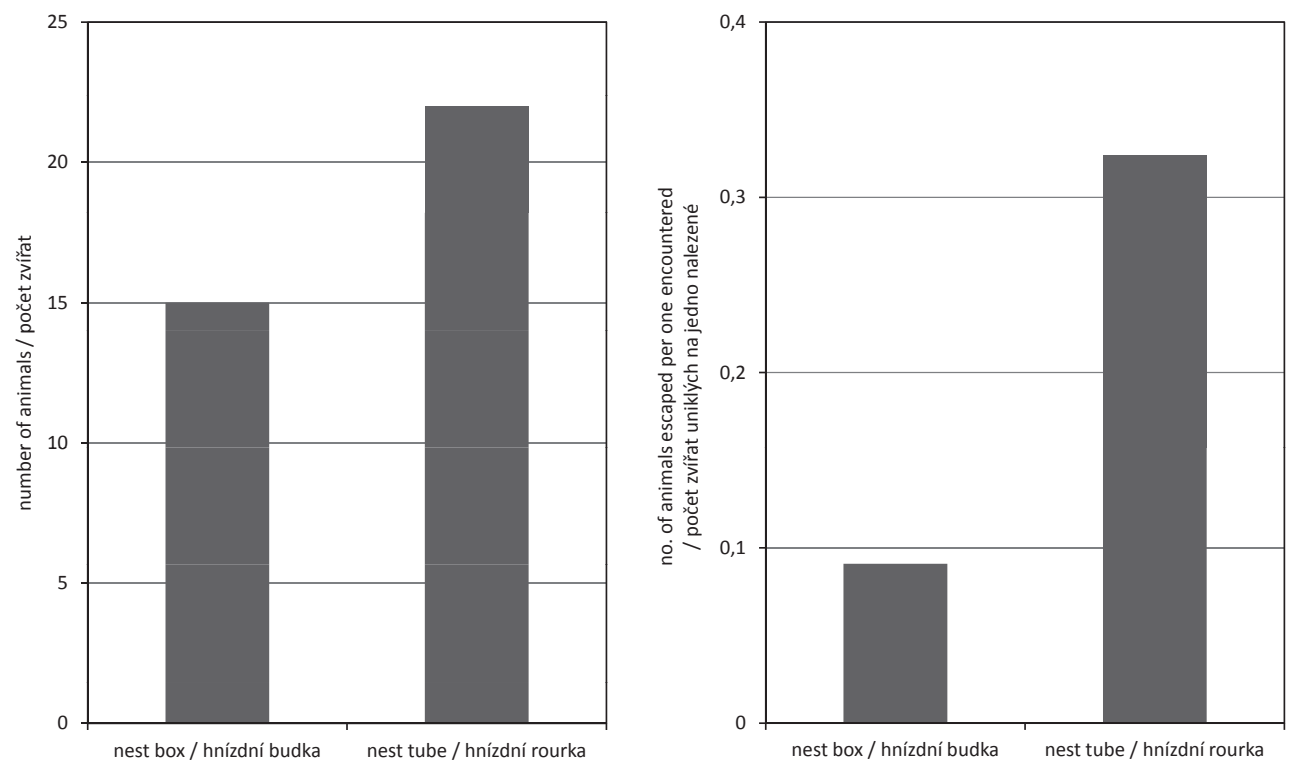

Figs. 1, 2. Results of testings of artificial shelters for hazel dormice; left - frequency of hazel dormice encountered in nest boxes and nest tubes when given the choice; right - frequency of escaped dormice per one dormouse encountered in nest boxes and nest tubes respectively.

Obr. 1, 2. Výsledky testování umělých úkrytů plšíka lískového; vlevo - četnost plšíků nalezených v hnízdních budkách a hnízdních rourkách, pakliže dostali na vybranou; vpravo - četnost uprchlých plšíků na jednoho plšíka nalezeného v hnízdních budce, respektive hnízdní rource. 
At the comparison sites, 37 adult animals were found. Fifteen of these animals were inside nest boxes and 22 of the animals were inside nest tubes (Fig. 1). This suggests that animals preferred nest tubes over nest boxes and that we found 1.5 times more animals inside nest tubes.

Of the 129 adult animals encountered in nest boxes or nest tubes $28(22 \%)$ escaped. In the tubes $23(32 \%)$ out of 71 animals escaped and in the nest boxes $5(9 \%)$ out of 55 animals escaped (Fig. 2). Which means animals escaped 3.6 times more often from nest tubes than from nest boxes.

\section{DISCUSSION}

Hazel dormice in our study clearly preferred nest tubes over nest boxes if both were present. These results are opposed to a study (CHANIN \& GUBERT 2011) where dormice used nest boxes more frequently than nest tubes and another study, where the use of nest boxes and tubes did not differ from each other (BULLION \& LoOSER in prep.).

Occupation of nest boxes by hazel dormice can be negatively affected by other species due to competition or predation (overview in JUŠKAITIS \& BÜCHNER 2013 and JUŠKAITIS 2014). Small entrance holes can exclude some of the bigger competitors such as edible dormice (Glis glis) and less damage from racoons (Procyon lotor) (GATTER \& SchÜtT 1999, Scherbaum-Heberer et al. 2012, BÜCHNER \& LANG unpubl. data). But they fail to exclude small competitors such as yellow-necked mice (Apodemus flavicollis) and wood mice (Apodemus sylvaticus) (VERBEYLEN 2017). In our study yellow necked and wood mice preferred nest boxes over nest tubes and where found about 4 times more often in nest boxes. In the presence of competitors and especially when they reach high densities, the use of nest boxes by hazel dormice may be lower than without competitors, which has to be considered when comparing performance of our methods. The same is true for the structure and size of the boxes used. Some studies showed that hazel dormice preferred specific types and sizes of nest boxes over others (SCHERBAUM-HEBERER et al. 2012, but see discussion in Vogel \& Duplain 2012, JušKaitis 2014). Therefore, preference of nest tubes over nest boxes in our study may have been an effect of competition that made the nest tubes more available for hazel dormice. What we do not know is what hazel dormice would do if only nest boxes are offered, without the possibility of choosing between tubes and boxes. CHANin \& GuberT (2011) report they had 10 out of 110 hazel dormice which were only caught in tubes and never in boxes, whereas three marked individuals were found in boxes and tubes alike. This could be due to a preference of different individuals to use either boxes or tubes and some will exclude one or the other. In our study it was not possible to prove individual preferences because every caught animal was translocated with the exception of females with very young litters ( $<14$ days). Due to individual preferences, there might also be site-specific differences, as some studies indicate a rather higher preference for nest boxes than for tubes (ChAnin \& Gubert 2011).

Regarding capturing animals for translocation purposes, nest boxes outperformed nest tubes because fewer animals escaped from them during monitoring surveys. This is a crucial and important fact because during translocations, the objective is to capture every single individual. If escaping cannot be avoided, it will diminish the success of the translocation exercise. Nest boxes showed the same overall performance compared to nest tubes in this study if all escaped animals were considered. In summary, 48 out of 71 animals in nest tubes and 50 out of 55 animals caught in nest boxes could be translocated. It has to be taken into account that there is no valid evidence that the same animals which were caught in nest tubes could not also be caught 
in nest boxes with no nest tubes nearby for them to choose. Therefore, nest boxes seem to be the better choice to capture animals for translocations (or other purposes when animals are required to be handled) as they offer the better escape ratio over nest tubes.

\section{SOUHRN}

Hnízdní budky a hnízdní rourky jsou široce využívány k mapování fauny, jak pro účely výzkumu, tak pro účely plánování hospodářského či stavebního využití krajiny, obzvláště při odhalování prítomnosti či různých typech výzkumu plšíka lískového (Muscardinus avellanarius). Pro porovnání účelnosti obou zmíněných typů zařízení, zhusta užívaných i pro přemist'ovací projekty, byla provedena studie hodnotící, jak plšíci uplatňují volbu mezi oběma zařízeními a jak účelné je tedy použití hnízdních budek či hnízdních rourek. Plšíci lískoví upřednostňovali hnízdní rourky před hnízdními budkami, ale při kontrolách častěji unikali z hnízdních rourek než z hnízdních budek. Výsledky testování obou zařízení tak ukazují, že pro přemist'ovací projekty jsou hnízdní budky lepší volbou než hnízdní rourky, nebot' nabízejí lepší poměr setrvání oproti úniku při kontrolách hnízdících jedinců.

Acknow ledgements

We thank L. GUBERT and R. JUŠKAITIS for very helpful comments on the original manuscript and P. MORRIS for language editing.

\section{REFERENCES}

Bright P. W. \& Morris P. A., 1994: Animal translocation for conservation: performance of dormice in relation to release methods, origin and season. Journal of Applied Ecology, 31: 699-708.

Bright P., Morris P. \& Mitchell-Jones T., 1996: A new survey of the dormouse Muscardinus avellanarius in Britain, 1993-4. Mammal Review, 26: 189-195.

Bright P., Morris P. \& Mitchell-Jones T., 2006: The Dormouse Conservation Handbook. Second Edition. English Nature, Peterborough, $74 \mathrm{pp}$.

Büchner S., Kretschmar C. \& Paul A., 2009: Die Große Nussjagd in Sachsen - Auf der Suche nach der Haselmaus. Natur und Landschaft, 84: 328-333.

BÜCHNER S., LANG J. \& JoKISCH S., 2014: Die aktuelle Verbreitung der Haselmaus Muscardinus avellanarius in Hessen. Jahrbuch Naturschutz in Hessen, 15: 123-125.

CHANin P. \& GuBert L., 2011: Surveying hazel dormice (Muscardinus avellanarius) with tubes and boxes: a comparison. Mammal Notes, 4: 1-6.

Chanin P. \& Woods M., 2003: Surveying Dormice Using Nest Tubes. Results and Experiences from the South West Dormouse Project. English Nature Research Report, 524. English Nature, Peterborough, 34 pp.

GATTER W. \& SснÜтt R., 1999: Langzeitentwicklung der Höhlenkonkurrenz zwischen Vögeln (Aves) und Säugetieren (Bilche Gliridae; Mäuse Muridae) in den Wäldern Baden-Württembergs. Ornithologischer Anzeiger, 38: 107-130.

JUŠKAITIS R., 1997: Use of nestboxes by the common dormice (Muscardinus avellanarius L.) in Lithuania. Natura Croatica, 6: 177-188.

JušKaitis R., 2014: The Common Dormouse Muscardinus avellanarius: Ecology, Population Structure and Dynamics. Nature Research Center, Vilnius, $196 \mathrm{pp}$.

JušKaitis R. \& BÜchner S., 2013: The Hazel Dormouse. NBB English Edition, Westarp Wissenschaften, Hohenwarsleben, $17 \mathrm{pp}$.

Marsh A. C. W. \& Morris P. A., 2000: The use of dor mouse Muscardinus avellanarius nest boxes by two species of Apodemus in Britain. Acta Theriologica, 45: 443-453. 
Morris P. A., Bright P. W. \& Woods D., 1990: Use of nest boxes by the dormouse (Muscardinus avellanarius). Biological Conservation, 51: 1-13.

Scherbaum-Heberer C., Koppmann-Rumpf B., Dukova S. \& Schmidt K.-H., 2012: Comparison of two nestbox types and their suitability for the common dormouse Muscardinus avellanarius. Peckiana, 8 : $167-172$.

VERBEYLEN G., 2017: How small should the entrance be? Is it possible to let common dormice Muscardinus avellanarius enter nest boxes and exclude other species? Apodemus, 14: 35-39.

Vogel P., Wey A. \& Schubnel E., 2012: Evaluation of Muscardinus avellanarius population density by nest box and by trap checking. Peckiana, 8: 141-149.

Vogel P. \& Duplain J., 2012: Testing the use of two types of nest box by the common dormouse (Muscardinus avellanarius). Peckania, 8: 157-165

Williams R. L., Goodenough A. E., Hrt A. G. \& Stafford R., 2013: Using long-term volunteer records to examine dormouse (Muscardinus avellanarius) nestbox selection. Public Library of Science One, 8(6): 1-9. 